\title{
18th Annual Conference of the International Society for Computer Aided Surgery
}

President: Makoto Hashizume, MD (J) 